\title{
Employee Engagement, Lingkungan Sosial dan Kinerja Karyawan di PT Bank Rakyat Indonesia Tbk, Kantor Cabang Bogor Dewi Sartika
}

\author{
Employee Engagement, Social Environment and Employee Performance in \\ PT Bank Rakyat Indonesia Tbk, Dewi Sartika Bogor Branch Office
}

\author{
Minkhaya Silviana Putri ${ }^{* *}$, Lukman M Baga ${ }^{2 \sharp}$, dan Euis Sunarti ${ }^{2 \sharp}$
}

\author{
${ }^{1}$ Magister Manajemen Bisnis, Sekolah Pascasarjana Institut Pertanian Bogor \\ 2 Program Pascasarjana Magister Manajemen Bisnis Institut Pertanian Bogor \\ "Jl Raya Pajajaran Bogor, email: lukmanmb@yahoo.com \\ email: euissunarti@yahoo.com
}

\begin{abstract}
ABSTRAK
Keterlibatan karyawan memengaruhi perubahan pola pikir dan perilaku yang ditentukan oleh kebutuhan, motivasi dan kepuasan kerja. Penelitian ini bertujuan menganalisis pengaruh keterlibatan karyawan, karakteristik karyawan terhadap kinerja karyawan di PT Bank Rakyat Indonesia (BRI). Teknik pengambilan sampel yang dipakai dalam penelitian ini adalah probability sampling, jumlah responden yang digunakan adalah 83. Metode analisis yang digunakan adalah analisis regresi berganda. Hasil penelitian ini menunjukan keterlibatan kerja dan lingkungan sosial karyawan tidak tetap memiliki kinerja lebih tinggi dibandingkan karyawan tetap. Karyawan tidak tetap perempuan lebih tinggi kinerjanya dibandingkan karyawan tidak tetap laki-laki. Komponen keterlibatan kerja dan lingkungan sosial yang berpengaruh terhadap kinerja adalah camaraderie, yaitu hubungan dengan rekan kerja dan kerjasama tim dan motivasi. Untuk itu, Bank BRI harus menjaga hubungan baik antar karyawan dan meningkatkan kerjasama tim.
\end{abstract}

Kata kunci : employee engagement, kinerja karyawan, lingkungan sosial

\begin{abstract}
Employee engagement influence the change of think pattern and behavior which supported by requirement, motivation and work satisfaction. This research aimed to study the influence of employee engagement, social environment on the employee performance in PT Bank Rakyat Indonesia (BRI). The sampling technique used in this study is a probability sampling, the number of respondents used is 83 . The method use multiple regression analysis. The result show of based on employee engagement and social environment the temporary employee have the higher performance than permanent employee. The woman temporary employee have the higher performance than man temporary employee. The component of employee engagement and social environment influenced performance is camaraderie that is employee relationship, team cooperation and motivation. Therefore, PT BRI must took care of good relationship inter employee and increase team cooperation.
\end{abstract}

Key word: employee engagement, employee performance, social environment

\footnotetext{
Korespondensi:

*) Jl Letjend. Suprapto Kav. 20 No. 14 Cempaka Putih Jakarta Pusat 10510; Telp. 0214212938, Hp.085711234060, email: minkhayasilviana@gmail.com, fax. 0214212940
} 


\section{PENDAHULUAN}

Pola pikir dan perilaku dalam bekerja selalu mengalami perubahan. Perubahan tersebut didorong oleh perubahan kebutuhan dan motivasi dalam pekerjaannya. Kebutuhan dan motivasi bekerja memiliki sifat kompleks, bukan hanya peningkatan taraf hidup tetapi juga keamanan, sosial, prestise dan pengembangan diri. Menurut Siagian (2008) motivasi bekerja meliputi keadilan, kewajaran, harapan dan kecocokan pekerjaan sebagai indikator teori kontenporer sumberdaya manusia dalam melihat karyawan. Sikap, perilaku dan produktivitas karyawan ditentukan oleh perhatian manajemen. Penelitan Robbertson dan Cooper (2009) menyatakan bahwa pemenuhan kesejahteraan karyawan dari sisi psikologis mampu meningkatkan loyalitas dan kinerja perusahaan. Sulistiyani dan Rosidah (2009) mengatakan apabila kebutuhan karyawan tidak terpenuhi, maka akan terjadi perilaku menyimpang dalam bekerja seperti ketidakhadiran, mogok kerja, protes dan perilaku negatif lainnya.

Sikap dan perilaku loyal karyawan sebagai output dari kepuasan kerja akan menguntungkan perusahaan. Penelitian Nurofia (2009) menunjukkan karyawan yang memiliki keterikatan akan lebih produktif, fokus kepada pelanggan, lebih aman dan minat keluar dari perusahaan rendah. Robbins dan Judge (2008) menyatakan oraganisasi yang memiliki lebih banyak karyawan yang lebih puas cenderung lebih efektif dibandingkan organisasi yang memiliki karyawan sedikit puas. Keterlibatan karyawan menghasilkan produktivitas yang lebih tinggi, pengingkatan kualitas produksi, kuantitas produksi, layanan pelanggan, peningkatan penjualan dan inisiatif manajemen.

Survei Marketing Research Intelligence (MRI) (2012) dalam Infobank 2012 menyatakan bahwa dua per tiga karyawan di Indonesia (70,13 juta jiwa) tidak memiliki keterlibatan dalam pekerjaannya. Mayoritas karyawan tidak bersunguhsungguh berupaya mencapai sasaran nilai perusahaan. Kondisi tersebut berlaku untuk perusahaan yang bergerak dalam industri jasa, termasuk bank. Bank sebagai salah satu perusahaan yang bergerak di bidang layanan perlu memperhatikan peningkatan keterampilan, keahlian dan kemampuan karyawan agar dapat memberikan pelayanan kepada nasabah secara prima. Pelayanan prima dapat diciptakan melalui mutu karyawannya.

Turnover karyawan bank di Indonesia mencapai $15 \%-20 \%$ per tahun dan jumlah tersebut lebih tinggi dibandingkan industri manufaktur kurang lebih 8\% (Wulandari, 2008). Hal tersebut menunjukan bahwa gaji yang tinggi di industri bank belum tentu berkorelasi positif kuat dengan komitmen dan loyalitas kerja. Di sisi lain, gaji dan jumlah karyawan tercatat sebagai beban operasional perusahaan.

PT Bank Rakyat Indonesia (BRI), Tbk tercatat sebagai bank yang membukukan laba bersih terbesar di Indonesia. BRI juga tercatat sebagai bank dengan jumlah karyawan terbanyak yaitu 85.530 (naik 12,97\% dibandingkan 2011) di tahun 2012, termasuk didalamnya 45.486 tenaga outsourcing (Infobank, 2013). BRI sebagai bank dengan jumlah karyawan terbanyak memiliki jumlah turnover karyawan tinggi. Tingginya tingkat turnover karyawan tersebut dipengaruhi oleh rendahnya motivasi, loyalitas dan keterlibatan karyawan terhadap perusahaan.

BRI Cabang Bogor Dewi Sartika (CBDS) membawahi tiga Kantor Cabang Pembantu (KCP), 23 Unit BRI dan lima Kantor Kas (KK). BRI CBDS merupakan cabang BRI yang memiliki turnover karyawan tinggi yaitu sebesar $20 \%$ pada 2013 . Hal tersebut dapat terjadi karena rendahnya keterlibatan kayawan dalam pekerjaan. Banyak perusahaan yang belum mampu mengatasi rendahnya tingkat keterlibatan karyawan. Dari kondisi tersebut, BRI CBDS perlu memahami faktor yang membentuk keterlibatan karyawan secara berkelanjutan. Kondisi tersebut akan membentuk karyawan dan tim yang memiliki kinerja tinggi dan adaptif terhadap perubahan organisasi dan memberikan kontribusi konstruktif.

Penelitian ini memiliki tujuan (1) menganalisis pengaruh keterlibatan karyawan dan lingkungan sosial terhadap kinerja karyawan beradasarkan status kepegawaian dan jenis kelamin; (2) Menganalisis pengaruh komponen keterlibatan karyawan dan lingkungan sosial terhadap kinerja karyawan; (3) Menganalisis perbedaan keterlibatan karyawan dan lingkungan sosial terhadap kinerja karyawan berdasarkan status kepegawaian dan jenis kelamin.

\section{METODE PENELITIAN}

Penelitian ini dilakukan di PT BRI Cabang Bogor Dewi Sartika (CBDS) menggunakan pendekatan analisis eksploratori, yaitu analisis yang digunakan untuk menganalisis hubungan karakteristik responden dan penilaian karyawan BRI CBDS dengan keterlibatan karyawan, karakteristik karyawan dan kinerja karyawan. Pendekatan 
kualitatif dilakukan melalui pengamatan dan pengumpulan data survei, dalam suatu populasi dengan kusioner dan wawancara terbuka.

Populasi dalam penelitian ini berjumlah 480 karyawan BRI CBDS yang terdiri dari karyawan tetap, karyawan kontrak dan karyawan outsourcing. Selanjutnya dipilih contoh menggunakan metode probability sampling secara obyektif, proporsional dan menggunakan estimasi parameter yang dapat dilakukan, bias dapat diperkirakan. Penentuan jumlah contoh menggunakan rumus Solvin (Umar, 2005):

$$
\mathrm{n}=\frac{\mathrm{N}}{1+\mathrm{N}(\mathrm{e})^{2}}
$$

Keterangan:

$\mathrm{n}=$ Jumlah karyawan yang dijadikan contoh

$\mathrm{N}=$ Ukuran Populasi

$\mathrm{e}=$ Nilai Kritis (batas ketelitian) yang diinginkan atau persen ketidaktelitian karena kesalahan pengambilan contoh populasi. Nilai e yang digunakan sebesar 0,10 (nilai kritis penelitian deskriptif)

Berdasarkan dari rumus Slovin maka jumlah responden yang digunakan adalah:

$$
\mathrm{n}=\frac{\mathrm{N}}{1+\mathrm{N}(e)^{2}}=\frac{480}{1+480(0.1)^{2}}=83
$$

\section{Definisi Operasional}

1. Employee Engagement $\left(\mathrm{X}_{1}\right)$ yang terdiri dari Equity dengan indikator kondisi kerja, kompensasi dan perasaan adil. Achievement dengan indikator tantangan pekerjaan, kesempatan berkembang, kemampuan bekerja, perasaan penting, penghargaan dan kebanggaan. Camaraderie dengan indikator hubungan rekan kerja, kerjasama tim dalam unit kerja, kerjasama tim antar unit kerja, kerjasama perusahaan secara keseluruhan. Leadership dengan indikator pemberian instruksi, pengambilan keputusan, dorongan semangat karyawan, komunikasi, pemberian bimbingan, penegakan disiplin, pengawasan karyawan, peneguran pada karyawan.

2. Karakteristik demografi $\left(\mathrm{X}_{2}\right)$ dengan indikator jenis kelamin,usia, pendidikan, pekerjaan, masa kerja, pendapatan dan status pernikahan.

3. Karakteristik Ekonomi $\left(X_{3}\right)$ dengan indikator tanggungan keluarga, jumlah aset, adanya hutang atau kredit, dan pendapatan lainnya.

4. Karakteristik Sosial $\left(\mathrm{X}_{4}\right)$ dengan indikator tiga peubah, yaitu ekonomi (status pekerjaan, pendapatan, dan gaya hidup), interaksi (peng- hargaan), politik (kekuasaan dan kepemimpinan) serta dapat ditambah dengan dukungan sosial.

5. Kinerja ( $\mathrm{Y}$ ) dengan indikator kuantitas pekerjaan/proses kerja, mutu kerja/hasil kerja, ketepatan waktu penyelesaian pekerjaan, kehadiran, kemampuan bekerjasama.

\section{Pengolahan Data}

Data yang diperoleh dari responden diolah dengan menggunakan skala diferensial semantik. Skala diferensial semantik adalah skala untuk mengukur sikap, tetapi bentuknya bukan pilihan ganda maupun checklist, tersusun dalam satu garis kontinum di mana jawaban sangat positif terletak dibagian kanan garis dan jawaban sangat negatif terletak dibagian kiri garis, atau sebaliknya. Ketepatan instrumen yang digunakan dalam pengambilan data dilakukan pengujian terhadap data yang diperoleh melalui pengujian validitas dan reliabilitas.

Validitas menunjukkan alat dapat mengukur apa yang ingin diukur (Umar 2005). Untuk uji validitas dilakukan dengan cara menghitung nilai korelasi ( $\mathrm{r}$ ) antara data pada masing-masing pernyataan dengan skor total memakai rumus teknik korelasi Product Moment Pearson berikut:

$$
\mathrm{r}=\frac{n \sum X Y-\left(\sum X\right)\left(\sum Y\right)}{\sqrt{\left\{\left(N \sum X^{2}\right)-\left(N \sum y^{2}\right)-\left(\sum y\right)^{2}\right\}}} \ldots \ldots \ldots(2)
$$

Keterangan:

$\mathrm{r}=$ Koefisien variabel yang dicari

$X=$ Skor masing-masing pertanyaan $X$

$\mathrm{Y}=$ Skor masing-masing pertanyaan $\mathrm{Y}$

$\mathrm{N}=$ Jumlah responden

Reliabilitas adalah suatu angka indeks yang menunjukkan konsistensi suatu alat pengukur di dalam mengukur gejala yang sama. Tingkat reliabilitas suatu konstruk atau peubah penelitian dapat dilihat dari hasil statistik cronbach alpha $(\alpha)$ Suatu peubah dikatakan reliable jika memberikan nilai cronbach alpha $>0,60$ (Ghozali, 2006).

$$
\mathrm{r}_{11}=\frac{\mathrm{K}}{(\mathrm{K}-1)}\left\{1-\frac{\sum \sigma^{2} \mathrm{~b}}{\sigma^{2} \mathrm{t}}\right\} \ldots
$$

Keterangan:

$\mathrm{r}_{11} \quad=$ keandalan instrumen

$\mathrm{k}=$ banyak butir pertanyaan

$\sigma^{2} \quad=$ ragam total

$\Sigma \sigma^{2} \mathrm{~b}=$ jumlah ragam total 
Analisis regresi merupakan prosedur yang kuat dan fleksibel dalam menganalisis hubungan asosiatif antara variabel independen $(X)$ dan variabel dependen $(Y)$. Seberapa besar pengaruh variabel independen terhadap variabel-variabel dependen, dapat diukur dengan besarnya nilai koefisien determinasi $\left(R^{2}\right)$ (Simamora dalam Sutrisno, 2009). Persamaan regresi berganda dalam penelitian ini adalah:

Hipotesis 1:

$Y_{1}: \beta o+\beta_{1} X_{1}+\beta_{2} X_{2}+\beta_{3} D_{3}+\beta_{4} D_{4}+\varepsilon i j \ldots$ (4)

Keterangan:

$\mathrm{Y} 1=$ Peubah kinerja karyawan

$\mathrm{X} 1=$ Peubah Employee Engagement

X4 $=$ Peubah Karakteristik Sosial

D1 = Dummy Status Kepegawaian

( $1=$ Karyawan tetap, $0=$ Karyawan tidak tetap)

D2 = Dummy Jenis Kelamin (1=Laki-laki, $0=$ Perempuan)

$\beta \mathrm{o}=$ Intercept

$\varepsilon \mathrm{ij}=$ Error

Hipotesis 2:

$Y_{1}: \beta O+\beta_{1} X_{1}+\beta_{2} X_{2}+\beta_{3} X_{3}+\beta_{4} X_{4}+\beta_{5} X_{5}+\beta_{6} X_{6}+\beta_{7} X_{7}$ $+\varepsilon i$.

Keterangan:

$\mathrm{Y} 1$ = Peubah kinerja karyawan

$\mathrm{X} 1$ = Peubah Equity

$\mathrm{X} 2$ = Peubah Echievement

$\mathrm{X} 3$ = PeubahCamaraderie

X4 = Peubah Leadership

X5 = Peubah Dukungan Sosial

X6 $=$ Peubah Proses Sosial di Tempat Kerja

$\mathrm{X} 7=$ Peubah Motivasi

$\beta \mathrm{o}=$ Intercept

$\varepsilon \mathrm{ij}=$ Error

Uji beda $t$-test digunakan untuk menentukan apakah dua contoh tidak berhubungan memiliki nilai rataan berbeda. Uji beda t-test dilakukan dengan membandingkan perbedaan antara dua nilai rataan dengan galat dari perbedaan rataan dua contoh. Uji beda $t$-test pada penelitian ini digunakan untuk melihat pada tingkat keterlibatan karyawaan lebih tinggi terdapat pada karyawan laki-laki atau karyawan perempuan.

Setelah koefisien masing-masing peubah dihasilkan, maka dilakukan uji kriteria statistik dan uji asumsi klasik. Pengujian kriteria statistik dimaksudkan untuk mengetahui apakah model yang digunakan merupakan model yang tepat untuk menggambarkan pengaruh antar peubah.

Uji $\mathrm{F}$ bertujuan menunjukkan apakah semua peubah independen yang dimasukkan ke dalam model secara simultan atau bersama-sama mempunyai pengaruh terhadap variabel dependen (Ghozali, 2006). Uji t adalah suatu uji untuk mengetahui signifikansi pengaruh peubah independen secara parsial atau individual terhadap peubah dependen (Ghozali, 2006).

Koefisien determinasi digunakan untuk melihat peubah bebas menerangkan keragaman untuk peubah terikatnya. Nilai $\mathrm{R}^{2}$ mengukur tingkat keberhasilan model regresi yang digunakan dalam memprediksi nilai peubah terikatnya.

Uji multikolonieritas untuk mendeteksi ada tidaknya multikolinearitas di dalam model regresi dapat dilihat dari nilai tolerance dan Variance Inflation Factor (VIF). Nilai Cut off yang sering dipakai untuk menjelaskan adanya multikolonieritas adalah nilai tolerance $<0.10$ atau sama dengan nilai VIF $>10$ (Ghozali, 2006).

Uji heterokodestisitas untuk menguji ketidaksaman ragam dari residual satu pengamatan ke pengamatan lain dalam model. Jika ragam dari residual satu pengamatan ke pengamatan lain tetap, maka disebut homoskedastisitas dan jika berbeda maka disebut heterokedastisitas (Ghozali, 2006).

\section{HASIL DAN PEMBAHASAN}

\section{Uji Validitas dan Reliabilitas}

Hasil uji validitas peubah karakteristik sosial menunjukkan nilai koefisien korelasi di atas 0,3, jika tanpa pertanyaan ke-6 dan ke-7, maka kuesioner yang digunakan valid. Hasil uji validitas peubah Employee Engagement menunjukkan nilai koefisien korelasi di atas 0,3 jika tanpa pertanyaan ke-5 dan ke-10 maka dapat dikatakan kuesioner yang digunakan valid. Hasil uji validitas peubah kinerja menunjukkan nilai koefisien korelasi di atas 0,3 maka dapat dikatakan kuesioner yang digunakan valid.

Pengujian uji reliabilitas instrumen karakteristik sosial memiliki koefisien $\alpha=0,829$, dimana Employee Engagement memiliki koefisien $\alpha=0,968$ dan kinerja memiliki koefisien $\alpha=0,887$, sehingga pengujian uji reliabilitas instrumen pada penelitian ini menunjukkan seluruh peubah yang digunakan memiliki koefisien cronbach alpha di atas 0,60. Hal ini menyimpulkan bahwa semua peubah dalam penelitian ini dinyatakan reliabel, maka 
dapat dilanjutkan untuk digunakan pada seluruh responden.

Pengaruh Employee Engagement dan Lingkungan Sosial terhadap Kinerja Karyawan Berdasarkan Status Kepegawaian dan Jenis Kelamin

Sebelum melakukan analisis regresi berganda telah dilakukan uji asumsi klasik (uji normalitas, uji multikolinearitas, dan uji heteroskedastisitas) pada data. Hasil uji tersebut tidak menunjukkan uji asumsi klasik, sehingga data layak dan dapat digunakan. Analisis regresi linier berganda digunakan untuk mengetahui pengaruh employee engagement dan lingkungan sosial terhadap kinerja berdasarkan status kepegawaian dan jenis kelamin. Model regresi bergandanya sebagai berikut:

kinerja $=2.85+0.318$ emplyoee engagement +0.274 lingkungan sosial - 0.037 status pegawai - 0.149 jenis kelamin

1. Jika pegawai tetap dan laki-laki (status pegawai=1) (jenis kelamin $=1$ )

kinerja $=2.664+0.318$ emplyoee engagement +0.274 lingkungan sosial

2. Jika pegawai tetap dan perempuan (status pegawai $=1$ ) (jenis kelamin $=0$ )

kinerja $=2.813+0.318$ emplyoee engagement +0.274 lingkungan sosial

3. Jika pegawai tidak tetap dan laki-laki (status pegawai $=0$ ) (jenis kelamin $=1$ )

kinerja $=2.701+0.318$ emplyoee engagement + 0.274 lingkungan sosial

4. Jika pegawai tidak tetap dan perempuan (status pegawai $=0$ ) (jenis kelamin $=0$ )

kinerja $=2.85+0.318$ emplyoee engagement + 0.274 lingkungan sosial.

Tabel 1. Faktor-faktor yang memengaruhi kinerja karyawan

\begin{tabular}{lll}
\hline Variabel & Koef & Sig \\
\hline Konstanta & 2.854 & 0.000 \\
Employee Engagement $\left(\mathrm{X}_{1}\right)$ & 0.318 & 0.000 \\
Lingkungan Sosial $\left(\mathrm{X}_{4}\right)$ & 0.274 & 0.002 \\
Status Kepegawaian $\left(\mathrm{D}_{1}\right)$ & -0.037 & 0.726 \\
Jenis Kelamin $\left(\mathrm{D}_{2}\right)$ & -0.149 & 0.181 \\
\hline Variabel Dependen & Kinerja & \\
$\mathrm{R}^{2}$ & 0.379 & \\
Adjusted $\mathrm{R}^{2}$ & 0.347 & \\
$\mathrm{~F}$ & 11.90 & \\
Sig. F & 0.000 & \\
\hline
\end{tabular}

Sumber: Data diolah (2015)
Berdasarkan hasil uji $t$ pada Tabel 1 diketahui $p$ value untuk lingkungan sosial dan employee engagement lebih kecil dari alpha 5\%, maka tolak $\mathrm{H}_{0}$ yang artinya lingkungan sosial dan employee engagement berpengaruh nyata terhadap kinerja karyawan dan keduanya berpengaruh positif. Sedangkan $p$ value status kepegawaian dan jenis kelamin di atas 5\%, maka terima $\mathrm{H}_{0}$ yang artinya status kepegawaian dan jenis berpengaruh secara negatif dan tidak signifikan terhadap kinerja karyawan.

Nilai uji F menunjukkan F hitung 11.90 dengan probililitas 0.000 lebih kecil dari 0.05, maka model regresi dapat digunakan untuk memprediksi kinerja atau dapat dikatakan employee engagement, lingkungan sosial, status kepegawaian, serta peubah jenis kelamin secara bersama-sama berpengaruh terhadap kinerja. Nilai koefisien Determinasi (adjusted $R^{2}$ ) 0.347 menunjukkan employee engagement dan karakteristik sosial dapat menerangkan $34,7 \%$ variasi kinerja, dan sisanya $(65.3 \%)$ dijelaskan oleh peubah lain yang tidak dimasukkan dalam model anaisis dalam penelitian ini.

Nilai peubah employee engagement $\left(\mathrm{X}_{1}\right)$ adalah 0.000 dimana hasil tersebut lebih kecil dari nilai nyata 0.05 dan bertanda positif, artinya peubah employee engagement berpengaruh nyata dan positif terhadap peubah kinerja. Koefisien regresi employee engagement 0,318, artinya jika nilai employee engagement naik satu satuan, maka rataan kinerja karyawan akan naik 0,318, dengan asumsi lingkungan sosial, status kepegawaian, dan jenis kelamin tetap.

Nilai dari peubah lingkungan sosial $\left(\mathrm{X}_{4}\right)$ adalah 0.002 lebih kecil dari nilai nyata 0,05 dan bertanda positif, artinya peubah lingkungan sosial berpengaruh nyata dan positif terhadap peubah kinerja. Koefisien regresi lingkungan sosial 0,274, artinya jika nilai lingkungan sosial naik satu satuan, maka rataan kinerja karyawan akan naik 0,274, dengan asumsi employee engagement, status kepegawaian dan jenis kelamin tetap.

Nilai dari peubah status kepegawaian (D1) adalah 0,726, dimana hasil tersebut lebih besar dari nilai nyata 0.05 dan bertanda negatif, artinya bahwa peubah status kepegawaian berpengaruh tidak nyata dan negatif terhadap peubah kinerja. Koefisien regresi status kepegawaian -0,037, artinya jika nilai status kepegawaian naik satu satuan maka rataan kinerja akan turun 0,037, dengan asumsi employee engagement, lingkungan sosial dan jenis kelamin tetap. 
Nilai dari peubah jenis kelamin $\left(\mathrm{D}_{2}\right)$ adalah 0,181 , dimana hasil tersebut lebih besar dari nilai nyata 0,05 dan bertanda negatif, artinya peubah status kepegawaian berpengaruh tidak nyata dan negatif terhadap peubah kinerja. Koefisien regresi status kepegawaian -0,149, artinya jika nilai status kepegawaian naik satu satuan, maka rataan kinerja akan turun 0,149, dengan asumsi employee engagement, lingkungan sosial dan peubah kinerja karyawan tetap. Karena bertanda negatif (-), maka kinerja pegawai tetap (1) laki-laki (1) paling rendah dibandingkan dengan kinerja pegawai tidak tetap (0) perempuan (0). Berdasarkan keterangan responden, pegawai tidak tetap perempuan memiiki kinerja lebih tinggi, karena memiliki motivasi tinggi.

Komponen Employee Engagement dan Lingkungan Sosial yang Memengaruhi Kinerja Karyawan

Sebelum melakukan analisis regresi berganda, dilakukan uji asumsi klasik (uji normalitas, uji multikolinearitas dan uji heteroskedastisitas) pada data. Hasil uji menunjukkan data layak dan dapat digunakan. Analisis regresi berganda digunakan untuk menganalisis pengaruh employee engagement dan lingkungan sosial terhadap kinerja.

Berdasarkan hasil uji $\mathrm{t}$ dapat diketahui bahwa hanya peubah Camaraderie yang memiliki $p$ value lebih kecil dari alpha $5 \%$, maka tolak $\mathrm{H}_{0}$, artinya Camaraderie nyata berpengaruh terhadap kinerja karyawan dan berpengaruh positif. Jika nilai Camaraderie naik satu satuan, maka rataan kinerja karyawan akan naik 0.235 dengan asumsi Equity, Echievement dan Leadership tetap.

Uji $\mathrm{F}$ menunjukkan $\mathrm{F}$ hitung 10,70 dengan probililitas 0,000, maka probabilitas lebih kecil dari 0,05 , sehingga model regresi dapat digunakan untuk memprediksi kinerja atau dapat dikatakan bahwa Camaraderie berpengaruh terhadap kinerja. Nilai koefisien Determinasi (adjusted $R^{2}$ ) yang diperoleh 0,324. Hal ini menunjukkan Camaraderie dapat menerangkan $32,4 \%$ variasi kinerja dan sisanya $(67,6 \%)$ dapat dijelaskan oleh peubah lain yang tidak dimasukkan dalam model anaisis dalam penelitian ini.

Nilai dari variabel Camaraderie adalah 0,018, dimana hasil tersebut lebih kecil dari nilai nyata 0,05 dan bertanda positif, artinya Camaraderie berpengaruh nyata dan positif terhadap variabel kinerja. Koefisien regresi Camaraderie 0,235, artinya jika Camaraderie semakin bertambah, maka kinerja akan meningkat 0.235 dengan asumsi peubah lainnya tetap.
Tabel 2. Komponen employee engagement yang memengaruhi kinerja karyawan

\begin{tabular}{lll}
\hline Variabel & Koef & Sig \\
\hline Konstanta & 3.577 & 0,000 \\
Equity & $-0,033$ & 0,693 \\
Echievement & 0,050 & 0,580 \\
Camaraderie & 0,235 & 0,018 \\
Lerdership & 0,157 & 0,054 \\
\hline Variabel Dependen & Kinerja & \\
$\mathrm{R}^{2}$ & 0,357 & \\
Adjusted $\mathrm{R}^{2}$ & 0,324 & \\
$\mathrm{~F}$ & 10,70 & \\
Sig. F & 0,000 & \\
\hline
\end{tabular}

Berdasarkan hasil uji t pada Tabel 2 dapat diketahui bahwa hanya motivasi yang memiliki $p$ value lebih kecil dari alpha 5\%, yaitu 0.000 artinya hanya motivasi nyata berpengaruh positif terhadap kinerja karyawan. Jika nilai motivasi naik satu satuan, maka rataan kinerja karyawan akan naik 0.394 dengan asumsi dukungan sosial dan proses sosial di tempat kerja tetap.

Nilai uji $\mathrm{F}$ menunjukkan bahwa $\mathrm{F}$ hitung 19,52 dengan probililitas 0,000 maka model regresi dapat digunakan untuk memprediksi kinerja atau motivasi berpengaruh terhadap kinerja. Nilai koefisien Determinasi (adjusted $R^{2}$ ) 0,407. Hal ini menunjukkan bahwa motivasi dapat menerangkan $40,7 \%$ variasi kinerja dan sisanya $(59,3 \%)$ dapat dijelaskan oleh peubah lain yang tidak dimasukkan dalam model analisis dalam penelitian ini.

Nilai dari peubah motivasi adalah 0,000, dimana hasil tersebut lebih kecil dari nilai nyata 0,05 dan bertanda positif, artinya motivasi berpengaruh nyata dan positif terhadap kinerja. Koefisien regresi motivasi 0,394 menyatakan bahwa jika motivasi semakin bertambah, maka kinerja akan meningkat 0,394, dengan asumsi peubah lainnya tetap.

Tabel 3. Komponen lingkungan sosial yang memengaruhi kinerja karyawan

\begin{tabular}{lll}
\hline Variabel & Koef & Sig \\
\hline Konstanta & 2,375 & 0,000 \\
Dukungan Sosial & 0,135 & 0,101 \\
Proses Sosial di Tempat Kerja & 0,074 & 0,288 \\
Motivasi & 0,394 & 0,000 \\
\hline Variabel Dependen & Kinerja & \\
R $^{2}$ & 0,429 & \\
Adjusted R & \\
F & 0,407 & \\
Sig. F & 19,52 & \\
\hline
\end{tabular}


Uji Beda Employee Engagement dan Kinerja Karyawan berdasarkan Status Kepegawaian, Jenis Kelamin dan Lingkungan Sosial

Uji beda digunakan untuk melihat perbedaan employee engagement dan kinerja karyawan berdasarkan status kepegawaian dan jenis kelamin. Status kepegawaian di BRI dibagi menjadi dua, yaitu karyawan tetap dan karyawan tidak tetap. Untuk karyawan tidak tetap sendiri dibagi atas karyawan kontrak dan karyawan outsorching.

Berdasarkan Tabel 4, hasil uji beda t-test didapatkan nilai $p$ value lebih besar dari 0.05, maka terima $\mathrm{H}_{0}$, artinya tidak ada perbedaan employee engagament dan kinerja karyawan berdasarkan karyawan tetap maupun karyawan tidak tetap. Uji beda t-test berdasarkan jenis kelamin dapat diketahui bahwa nilai $p$ value lebih besar dari 0.05 , maka terima $\mathrm{H}_{0}$, artinya tidak ada perbedaan employee engagament dan kinerja karyawan berdasarkan jenis kelamin, yaitu lakilaki dan perempuan.

Tabel 4. Nilai uji beda employee engagement dan kinerja karyawan berdasarkan status kepegawaian dan jenis kelamin

\begin{tabular}{lccc}
\hline \multicolumn{1}{c}{ Kategori } & Variabel & F & Sig. F \\
\hline Status Kepega- & EE & 1.116 & 0.294 \\
waian & KK & 1.175 & 0.282 \\
\hline \multirow{2}{*}{ Jenis Kelamin } & EE & 1.434 & 0.235 \\
& KK & 0.501 & 0.481 \\
\hline
\end{tabular}

Keterangan: $\mathrm{EE}=$ employee engagement, $\mathrm{KK}=$ kinerja karyawan

Uji beda dilakukan untuk melihat perbedaan komponen employee engagement dan lingkungan sosial dengan kinerja karyawan berdasarkan karyawan tetap dan karyawan tidak tetap. Berdasarkan hasil uji beda t-test pada Tabel 5 diketahui hanya Camaraderie yang memiliki nilai $p$ value lebih kecil dari 0.05 , maka tolak $\mathrm{H}_{0}$, artinya terdapat perbedaan Camaraderie antara karyawan tetap dengan karyawan tidak tetap.

Tabel 5. Uji beda komponen employee engagement dan lingkungan sosial

\begin{tabular}{ll}
\hline Variabel & Sig \\
\hline Equity & 0.518 \\
Achievement & 0.670 \\
Camaraderie & 0.017 \\
Leadership & 0.444 \\
Dukungan Sosial & 0.835 \\
Proses Sosial di Tempat Kerja & 0.944 \\
Motivasi & 0.301 \\
\hline
\end{tabular}

\section{Implikasi Kajian}

Implikasi manajerial bagi PT BRI Cabang Bogor Dewi Sartika adalah :

1. Terkait employee engagement

Camaraderie merupakan komponen dari peubah employee engagement yang paling dominan terhadap kinerja. Bank BRI harus meningkatkan hubungan baik karyawan, baik sesama rekan kerja maupun dengan pimpinan dan bawahan, serta kerjasama tim agar lebih ditingkatkan lagi, sehingga dapat meningkatkan kinerja karyawan.

2. Terkait lingkungan sosial

Motivasi merupakan komponen dari peubah lingkungan sosial yang paling dominan terhadap kinerja. Bank BRI harus meningkatkan motivasi karyawan dengan insentif, bonus, lingkungan kerja yang nyaman, pemimpin yang terus memotivasi dengan dorongan dan bimbigan, serta tuntutan perkembangan orgaisasi atau tugas.

\section{KESIMPULAN}

Karyawan tidak tetap perempuan memiliki kinerja lebih baik dibandingan dengan karyawan tetap laki-laki, dikarenakan karyawan tidak tetap perempuan memiliki motivasi tinggi untuk menjadi karyawan tetap. Komponen employee engagement dan lingkungan sosial yang berpengaruh terhadap kinerja adalah camaraderie, yaitu hubungan dengan rekan kerja dan kerjasama tim dan motivasi.

Hasil uji beda menunjukan antara employee engagement dengan kinerja karyawan menurut status kepegawaian dan jenis kelamin tidak ada perbedaan, tetapi jika dilihat setiap komponen peubahnya terdapat perbedaan pada camaraderie antara karyawan tetap dan karyawan tidak tetap.

\section{DAFTAR PUSTAKA}

Ferdian, Rully. 10 Bank dengan Karyawan Terbanyak. Infobank. Tersedia: http://www. infobanknews.com/2012/05/10-bank-dengan-karyawan-terbanyak/ (26 April 2013)

Ghozali, Imam. 2006. Aplikasi Analisis Multivariate dengan Program SPSS. Badan Penerbit Undip, Semarang.

Kurniasi, Apriani. Kelangkaan SDM Picu Kenaikan Gaji. Infobank. Tersedia: http://www.infobanknews.com/2013/01/kel 
angkaan-sdm-picu-kenaikan-gaji/-(20 Maret 2013)

Nurofia, Fifie. 2009. Mengenal employee management. JournalPsikologi Maranatha 6(6): 1-16

Robbertson, Ivan T,Cooper, Cary L.2009. Full engagement: the integration of employee engagement \&psychological wellbeing. Journal Leadership and Organization Development. 31(4): 324-336.

Robbins, Stephen P, Judge, Timothy A. 2008. Perilaku Organisasi: Organizational Behavior. Salemba Empat. Jakarta (ID).

Siagian, Sondang P. 2008. Manajemen Sumber Daya Manusia. Bumi Aksara, Jakarta (ID).
Sulistiyni, Teguh A, Rosidah. 2009. Manajemen Sumber Daya Manusia: Konsep, Teori dan Pengembangan dalam Konteks Organisasi Publik. Andi, Yogyakarta (ID).

Sutrisno, Edy. 2009. Manajemen Sumber Daya ManusiaEdisi 1. Kencana, Jakarta (ID).

Umar, Husein. 2005. Metode Penelitian: Untuk Skripsi dan Tesis Bisnis. Raja Grafindo Persada, Jakarta (ID).

Wulandari, P. (2008). Turnover tidak akan menjadi masalah kembali bagi perusahaan. Tersedia di http://managedaily.co.id/journal/index/category/human_resources/131/6 50 diakses pada tanggal 3 April 2013 